\title{
Effects of Aeration Flow Rate in the Culture Medium on the Growth Performance and Egg Production of Copepod Oithona similis Fed with Fermented Organic Diet
}

\author{
Diana Chilmawati ${ }^{1,2, *}$,Johannes Hutabarat $^{2}$,Sutrisno Anggoro ${ }^{3}$, and Suminto Suminto ${ }^{2}$ \\ ${ }^{1}$ Doctoral Program of Coastal Resources Management. Department of Aquatic Resources. Faculty of \\ Fisheries and Marine Science.Diponegoro University. Jln. Prof Soedarto. SH.Tembalang. Semarang \\ 50275. Indonesia \\ ${ }^{2}$ Department of Aquaculture. Faculty of Fishery and Marine Science. Diponegoro University. Jln. \\ Prof Soedarto. SH. Tembalang. Semarang 50275 Indonesia \\ ${ }^{3}$ Department of Aquatic Resources Management. Faculty of Fishery and Marine Science.Diponegoro \\ University, Indonesia.
}

\begin{abstract}
The availability of copepod Oithona similis as live food organism for shrimp and marine fish larvae is strongly influenced by the optimum feed and environment conditions. Optimization of dissolved oxygen (DO) for $O$. similis can be carried out by providing proper aeration in culture media. Feeding with fermented organic diet besides phytoplankton is expected to support the individual growth, metabolism, and reproduction of $O$. similis. The aim of this study was to examine the effect of different aeration flow rates on the growth performance and egg production of $O$. similis and to determine the optimum aeration flow rate. Completely Randomized Design Experiment used in this study with 4 treatments and 4 replications. The treatment was $O$. similis culture with different aeration flow rate of $0.00 ; 22.00 ; 45.67 ; 66.67 \mathrm{~mL}_{\text {.second }}{ }^{-1}$. The results showed that the difference aeration flow rate significantly affected $(\mathrm{p}$ $<0.05)$ the growth performance and egg production of $O$. similis. The aeration flow rate of $45.67 \mathrm{~mL} . \mathrm{second}^{-1}$ provided the best growth performance with total density of $81.25 \pm 2.99$ ind. $\mathrm{mL}^{-1}$; population specific growth rate $0.220 \pm 0.002$ day $^{-1}$; and egg production $28.40 \pm 0.48$ eggs.ind $^{-1}$. Moreover, the optimum aeration flow rate culture medium for $O$. similis is 45.70 mL.second ${ }^{-1}$.
\end{abstract}

\section{Introductions}

The utilization of copepods provided higher growth and survival of marine fish larvae than artificial feed [1]. Some research revealed the success of the use of copepods as live food for shrimp and marine fish larvae have been widely carried out, including [2]. To date, Oithona $\mathrm{sp}$. is one of the Cyclopoid copepods that are abundant in Indonesian waters. Its potentially used as live food organisms, and more widely used in hatcheries of sea shrimp and other marine fish larvae than Artemia and Rotifer [1].

\footnotetext{
*Corresponding author: dianachilmawati@yahoo.com
} 
Oithona sp. isolated from Indonesian coastal waters have been identified and classified as Oithona similis, which grow optimally at salinity of 19.4 ppt [3]. O. similis grow well by giving phytoplankton cells namely Chaetoceros calcitrans, and also grows very well when given $50 \%$ fermented organic feed [4].

The availability of copepods including $O$. similis as larval feed is affected by media quality and optimum environment condition [1]. Environmental factors, i.e. temperature and dissolved oxygen (DO) are essential for the production of nauplii copepods, individual growth rate, and metabolism [5]. In $O$. similis culture, DO is one of environmental factors which has a role in metabolism processes. Increase in DO in culture media might be done through aeration at proper flow rate in semi mass culture production. Optimization of DO for $O$. similis can be carried out by providing some amount of aeration flow rate into the culture media. Therefore, research about the effect of aeration flow rate in the culture media is very important to determine its optimum point for supporting $O$. similis growth at high density.

\section{Material and Method}

This study was conducted at the Coastal Area Development Laboratory, Faculty of Fisheries and Marine Science, Diponegoro University, Jepara Campus, Central Java, Indonesia from July to September 2018.

The temperature and $\mathrm{pH}$ of $O$. similis culture media were daily measured using Amtast EC910 Multiparameter. Meanwhile, Ammonia content was measured using Indophenol Spectrophotometer Method.

\subsection{Preparation of fitoplankton culture and fermented organic feed}

C. calcitrans was provided by the Life Feed Laboratory, Laboratory of Brackish Water Aquaculture Development Research Center (BWADRC) Jepara, Central Java, Indonesia. This phytoplankton was cultured at sterile sea water at $25-28^{\circ} \mathrm{C}, 28-30 \mathrm{ppt}$ of salinity, and $\mathrm{pH} 8$-9. The sea water was sterilized by adding $60 \mathrm{mg}$. $\mathrm{L}^{-1}$ of Sodium Hypochlorite $(\mathrm{NaClO})$ for 10-30 minutes, and neutralized with $80 \mathrm{mg} . \mathrm{L}^{-1}$ of Sodium Thiosulphate $\left(\mathrm{NaS}_{2} \mathrm{O}_{3}\right)$ for 24 hours with continuous aeration. The culture was carried out in $60 \mathrm{~L}$ plastic tube containing $40 \mathrm{~L}$ sterilized seawater using a modified Walne media at a dosage of $0.5 \mathrm{ml} . \mathrm{L}^{-1}$ with a 24 hours light photoperiod and at 1500 to 1800 lux and controlled aeration. The volume of inoculant of $C$. calcitrans was $10 \%$ from the total volume of medium culture (Lee et al., 1996). The density of $C$. calcitrans was observed every day by taking a sample of the microalgae and then counted under a microscope (Olympus CH20) 10x magnification with a hemocytometer (Improved Neubauer volume $0.0025 \mathrm{~mm}^{3}$ ).

The fermented organic feed used the combination of organic materials of tofu flour, rice bran and fish flour in powder form with an average diameter range of 50-100 $\mu \mathrm{m}$ [4]. The content of fermented organic feed protein was $30 \%$. The plastic tube was filled $10 \mathrm{~mL}$ of EM4 probiotic containing Lactobacillus casei, Saccharomyces cerevisiae, and Bacillus sp. Then, the mixture was filled with $200 \mathrm{~mL}$ sterilized water and $25 \mathrm{~mL}$ molasses for $1 \mathrm{~kg}$ of mixed organic feed. The incubation was conducted for 48 hours before being used.

\subsection{Culture conditions of Oithona similis}

$O$. similis was obtained from the culture collection of the Marine Culture Development Research Center MCDRC) in Lampung, Indonesia [3]. The $O$. similis culture was carried out in a $15 \mathrm{~L}$ of volume container with $8 \mathrm{~L}$ of sterile seawater at $19.44 \mathrm{ppt}$ of salinity [3], at 27$28{ }^{\circ} \mathrm{C}, \mathrm{pH} 8$, with a innitial stocking density of 1 ind. $\mathrm{mL}^{-1}$ [8] for 20 days. The density of $C$. 


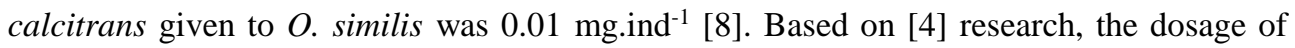
fermented organic feed was 0.5 g.L $\mathrm{L}^{-1}$ of culture media with the combinations of $50 \%$ phytoplankton cell and 50\% of fermented organic feed [9]. Aeration flow rate treatments were established at $0.00 ; 22.00 ; 45.67$; and $66.67 \mathrm{~mL}$. second ${ }^{-1}$ by using flow meter (Matheson FM-1050-VIA Part No. 7642T-603). The population of $O$. similis at the nauplii, copepodite, and adult stages was observed under a microscope (Olympus CYK41). Each stadia is determined based on its morphology [10].

\subsection{Design of experiment}

A completely randomized design with 4 treatments and 4 replications was carried out in this study. The treatments were A $(O$. similis cultured with an aeration flow rate of 0.00 mL.second $\left.{ }^{-1}\right)$ B (22.00 mL.second $\left.{ }^{-1}\right), C$ (45.67 mL.second $\left.{ }^{-1}\right)$, and D $\left(66.67 \mathrm{~mL}\right.$.second $\left.{ }^{-1}\right)$. The density of $O$. similis was calculated every 4 days to obtain the total population, growth performance, and egg production. Calculation of total $O$. similis density consists of nauplii, copepodites, adult and female eggs laying densities. Calculation of the amount of $O$. similis was observed carefully using a microscope, magnifying glass, Petri dish, and dropper drops with adequate lighting. Samples were taken from $100 \mathrm{~mL} \mathrm{O}$. similis culture from each treatment. Egg production was calculated by comparing the abundance of eggs and the number of females laying eggs. Calculation of the number of eggs was done by randomly isolating $O$. similis to lay eggs from each treatment $(\mathrm{n}=2)$. The egg-laying female was observed under a 10x - 40x magnification microscope. Egg abundance was calculated by multiplying the number of egg sacs by the average number of eggs per bag [11].

\subsection{Data collection and statistical analysis}

The density of $O$. similis was counted every 4 days during 20 days observations. Amount of $50 \mathrm{~mL}$ sub sample was taken from the culture medium to calculate the number of total $O$. similis, population specific growth rate (r) and egg production.

Growth performance was calculated using a formula by [12]:

$$
r=\frac{\ln \ln N t-\ln \ln N o}{t}
$$

Where $\mathrm{r}$ is population growth $\left(\mathrm{day}^{-1}\right)$, Nt is the final density of $O$. similis, No is an initial density of $O$. similis and tis days needed to achieve maximum growth.

Egg production is the number of eggs produced by the female $O$. similis on average during their lifetime according to [11]:

$$
\text { Egg production }=\frac{\Sigma s \times e}{\Sigma n}
$$

Where $\mathrm{s}$ is the amount of egg sac, e is the average amount of eggs per sac and $\mathrm{n}$ is the number of ovigerous females (ind).

Data were analyzed by One Way Analysis of Variance (ANOVA) to determine the effect of different aeration flow rate on growth performance and egg production of $O$. similis. Least Significant Different (LSD) test $(\alpha=0.05)$ by using SPSS 16 was conducted when the treatment had a significant effect. The optimum point of aeration rate flow is determined using polynomial orthogonal analysis with the MAPLE program 2016.

\section{Result and Discussion}




\section{a. Result}

\subsubsection{Water quality in the difference aeration flow rate of $O$. similis culture medium}

The treatment of different aeration flow rates of $O$. similis culture media provides different dissolved oxygen content (Figure 1). The measurement results of Dissolved Oxygen (DO) content in each treatment showed digression from the first day of culture to the last day of the observation $\left(20^{\text {th }}\right.$ day). The treatment of $0.00 \mathrm{~mL}^{-}$second ${ }^{-1}$ aeration flow rate showed the lowest DO (2.50 mg. $\left.\mathrm{L}^{-1}\right)$ compared to the other three treatments. The DO measurement results at the end of each observation were as follows: aeration flow rate of $66.67 \mathrm{~mL}^{-s^{-}}$sond $^{-}$ ${ }^{1}$ produced the highest DO $\left(4.41 \pm 0.06 \mathrm{mg} . \mathrm{L}^{-1}\right), 45.67 \mathrm{~mL} . \mathrm{second}^{-1}$ aeration flow rate produced DO of $4.18 \mathrm{mg} . \mathrm{L}^{-1}$, and $22.00 \mathrm{~mL}$. second ${ }^{-1}$ aeration flow rate produced DO of 3.74 mg. $\mathrm{L}^{-1}$.

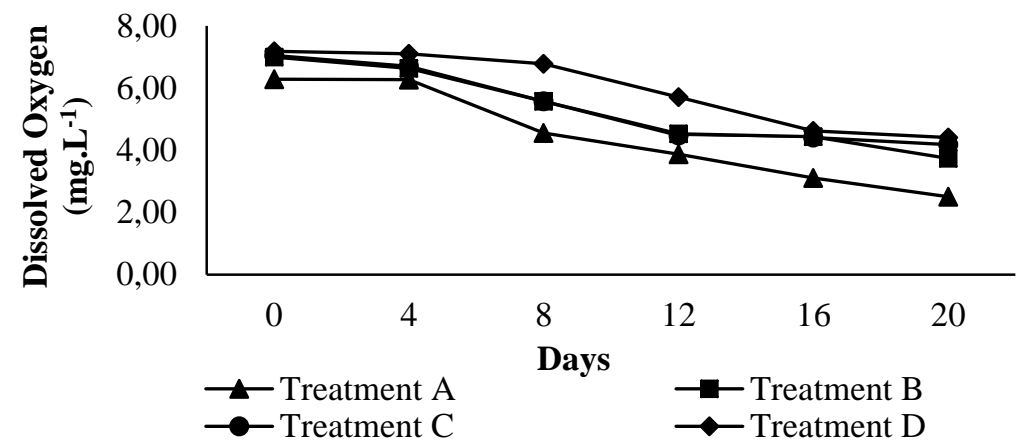

Fig. 1. Dissolved oxygen content at different aeration flow rate culture medium of $O$. similis during the observation

The relationship between DO and aeration flow rate (Figure 2) showed a simple linear relationship with a regression equation $\mathrm{y}=0.0276 \mathrm{x}+2.7799$ with $\mathrm{R}^{2}=0.8658$, which means that $86.58 \%$ DO of $O$. similis culture media was influenced by aeration flow rate factors and $13.42 \%$ was influenced by another factor.

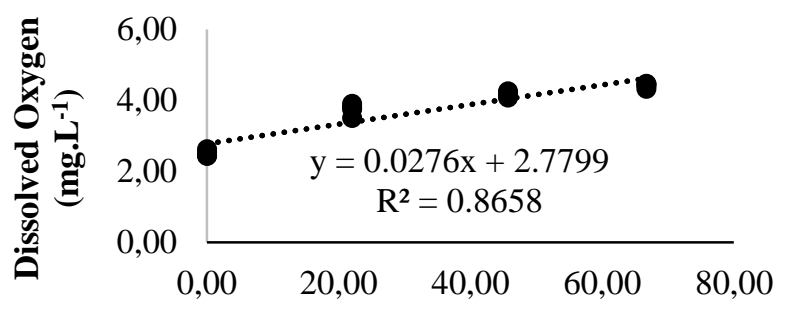

Aeration Flow Rate (mL.second ${ }^{-1}$ )

Fig. 2. Relationship between aeration flow rate and Dissolved Oxygen culture medium of $O$. similis

The average content of $\mathrm{DO}, \mathrm{pH}$, and Ammonia of $O$. similis culture media during the study (Table 1) showed a favourable levels for $O$. similis.

Tabel 1. Average content of $\mathrm{DO}, \mathrm{pH}$, and Ammonia of $O$. similis culture media during the study

\begin{tabular}{|c|c|c|c|c|}
\hline \multirow{2}{*}{$\begin{array}{c}\text { Aeration flow } \\
\text { rate } \\
\left(\mathrm{mL}_{\mathrm{s} \text { second }}{ }^{-1}\right)\end{array}$} & \multicolumn{2}{|c|}{ Temperature $\left({ }^{\circ} \mathrm{C}\right)$} & \multirow{2}{*}{$\mathrm{pH}$} & Ammonia $\left(\mathrm{mg} . \mathrm{L}^{-1}\right)$ \\
\cline { 2 - 3 } & Morning & Evening & & \\
\hline 0.00 & $25.40 \pm 0.18$ & $27.43 \pm 0.05$ & $7.84 \pm 0.04$ & $0.128 \pm 0.003$ \\
\hline
\end{tabular}




\begin{tabular}{|l|l|l|l|l|}
\hline 22.00 & $25.16 \pm 0.14$ & $27.30 \pm 0.00$ & $7.93 \pm 0.03$ & $0.056 \pm 0.001$ \\
\hline 45.67 & $25.20 \pm 0.16$ & $27.23 \pm 0.15$ & $7.85 \pm 0.04$ & $0.000 \pm 0.001$ \\
\hline 66.67 & $25.30 \pm 0.04$ & $27.38 \pm 0.15$ & $7.93 \pm 0.00$ & $0.000 \pm 0.001$ \\
\hline
\end{tabular}

\subsubsection{O. similis population}

The difference in the aeration flow rate on culture media significantly affected ( $\mathrm{p}<0.05)$ on $O$. similis growth performance. Total density was the total number of nauplius, copepodites and adult copepods, including an adult with eggs. According to the results of each stage of $O$. similis on the last day of cultivation (Day 20), it was indicated that the lowest density was $45.67 \mathrm{~mL}$.second ${ }^{-1}$ (Table 2). The results of the observations on day 20 showed that at the aeration flow rate of 45.67 and $66.67 \mathrm{~mL}$.second ${ }^{-1}$ the population was dominated by $O$. similis stage copepodite. Whereas at an aeration flow rate of 0.00 and $22.00 \mathrm{~mL}_{\text {.second }}{ }^{-1}$ the population was dominated by $O$. similis stage copepodite.

Table 2. Numbers of nauplii, copepodite, adult and population of $O$. similis in different aeration flow rate culture media on the last day of cultivation (ind. $\mathrm{mL}^{-1}$ )

\begin{tabular}{|c|c|c|c|c|}
\hline \multirow{2}{*}{$\begin{array}{c}\text { Aeration flow } \\
\text { rate } \\
\left(\mathrm{mL} . \text { second }^{-1}\right)\end{array}$} & Nauplii & Copepodite & Adult & Population* $^{*}$ \\
\cline { 2 - 5 } & $6.25 \pm 1.71$ & $4.75 \pm 0.96$ & $6.75 \pm 2.63$ & $17.75 \pm 1.71^{\mathrm{d}}$ \\
\hline 0.00 & $27.50 \pm 2.08$ & $25.25 \pm 1.71$ & $21.25 \pm 2.22$ & $766.67 \pm 1.41^{\mathrm{c}}$ \\
\hline 22.00 & $22.25 \pm 1.71$ & $30.00 \pm 1.63$ & $29.00 \pm 2.16$ & $81.25 \pm 2.99^{\mathrm{a}}$ \\
\hline 45.67 & $25.00 \pm 2.16$ & $27.50 \pm 2.52$ & $24.75 \pm 2.22$ & $77.25 \pm 2.06^{\mathrm{b}}$ \\
\hline 66.67 & &
\end{tabular}

$*$ Mean \pm SD. Different lowcase letter indicate a significant difference between treatment at $\mathrm{p}<0.05$

The different aeration flow rates had a different effect on the population of $O$. similis for 20 days of observation (Figure 3 ). The $0.00 \mathrm{~mL}$.second ${ }^{-1}$ aeration flow rate provides the lowest density compared to other aeration flow rates. $45.67 \mathrm{~mL}$.second ${ }^{-1}$ aeration flow rate is proven to provide the highest density compared to aeration flow rates of 66.67 and 22.00 mL.second ${ }^{-1} O$. similis density increased from the first observation, namely the $4^{\text {th }}$ day, and continued to increase until the $20^{\text {th }}$ day observation.

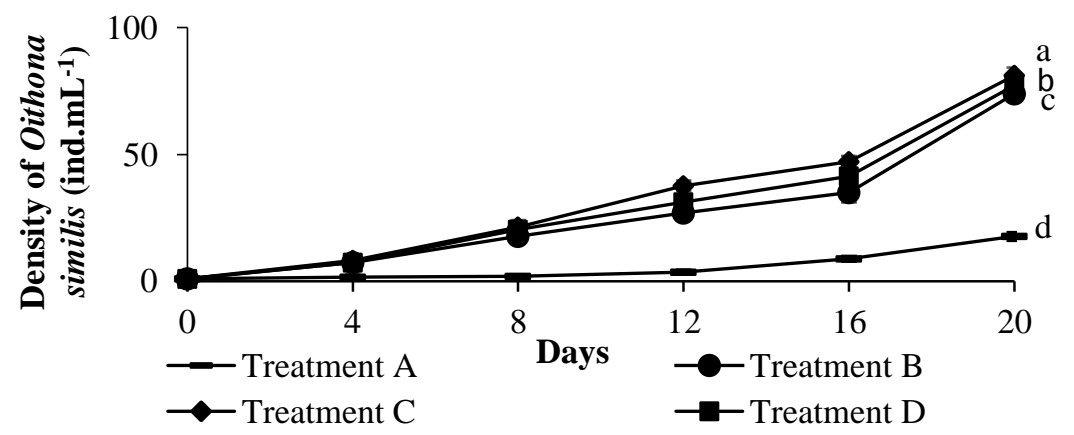

Figure 3. The density of $O$. similis at different aeration flow rate during 20 days culture period. Values not sharing the same letter are different significantly from one another $(p<0.05)$ by Least Significant Difference Test 
The correlation between aeration flow rate and total density shows a quadratic relationship patterned equation $\mathrm{y}=-0.0307 \mathrm{x}^{2}+2.8801 \mathrm{x}+19.752$ with $\mathrm{R}^{2}=0.9668$, which means that $96.68 \%$ of total $O$. similis density is influenced by aeration flow rate factors and $3.32 \%$ is influenced by factors other. The $O$. similis total density response curve for the aeration flow rate (Figure 4) shows the optimum point of the aeration flow rate at 45.90mL.second ${ }^{-1}$.

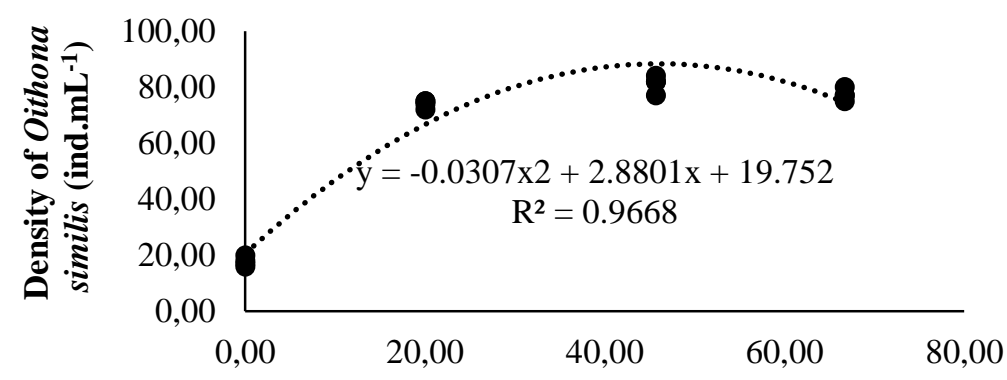

Aeration Flow Rate Culture Medium (mL.second ${ }^{-1}$ )

Figure 4. Corellation between aeration flow rate and density of $O$. similis

\subsubsection{The population specific growth rate of $O$. similis.}

The difference of aeration flow rates showed a significant effect $(\mathrm{p}<0.05)$ on the specific growth rate of $O$. similis population (Figure 5). The highest value of population specific growth rate $(\mathrm{r})\left(0.220 \pm 0.002 \mathrm{day}^{-1}\right)$ was shown in $O$. similis culture at giving an aeration flow rate of $45.67 \mathrm{~mL}$.second ${ }^{-1}$. The aeration flow rates of 66.67 and $22.00 \mathrm{~mL}$. second $^{-1}$ give $\mathrm{r}$ values that are not significantly different, each at $0.216 \pm 0.001$ and $0.215 \pm 0.001$ day $^{-1}$. The lowest population specific growth rate $\left(0.144 \pm 0.005\right.$ day $\left.^{-1}\right)$ was shown in culture media with an aeration flow rate of $0.00 \mathrm{~mL} \cdot$ second $^{-1}$.

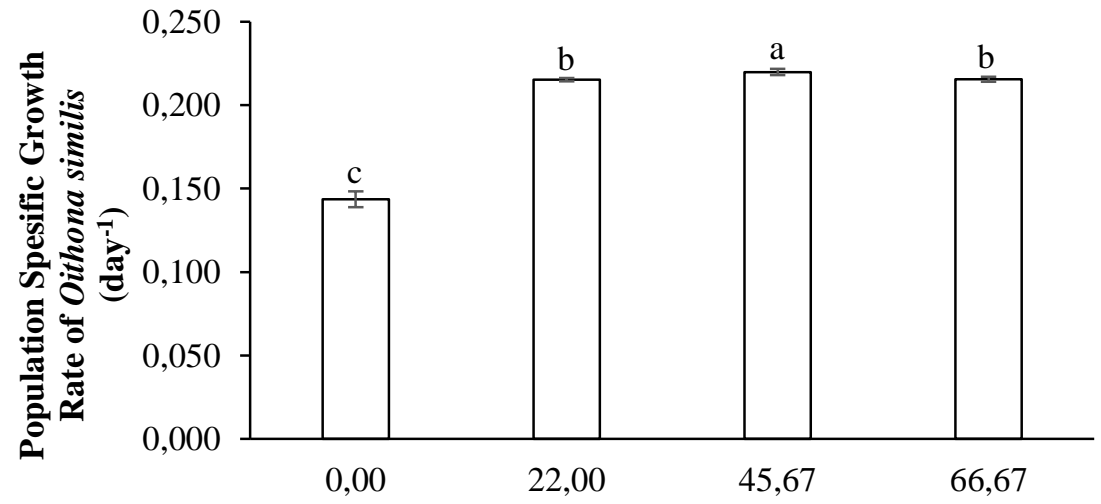

Aeration Flow Rate Culture Medium (mL.second ${ }^{-1}$ )

Figure 5. Histogram of the population specific growth rate of $O$. similis in different aeration flow rate culture media

The curve of $O$. similis specific population growth rate during the study with differences in aeration flow rate (Figure 6) showed there was quadratic pattern correlation relationship with the equation $y=-4 \mathrm{E}-05 \mathrm{x}^{2}+0.0036 \mathrm{x}+0.1467$ with $\mathrm{R}^{2}=0.9511$. This means $95.11 \%$ of the population specific growth rate was influenced by differences in the aeration flow rate of culture media and $4.89 \%$ influenced by other factors. The optimum point of aeration flow rate was $O$. similis culture medium at $45.00 \mathrm{~mL}$. second ${ }^{-1}$. 


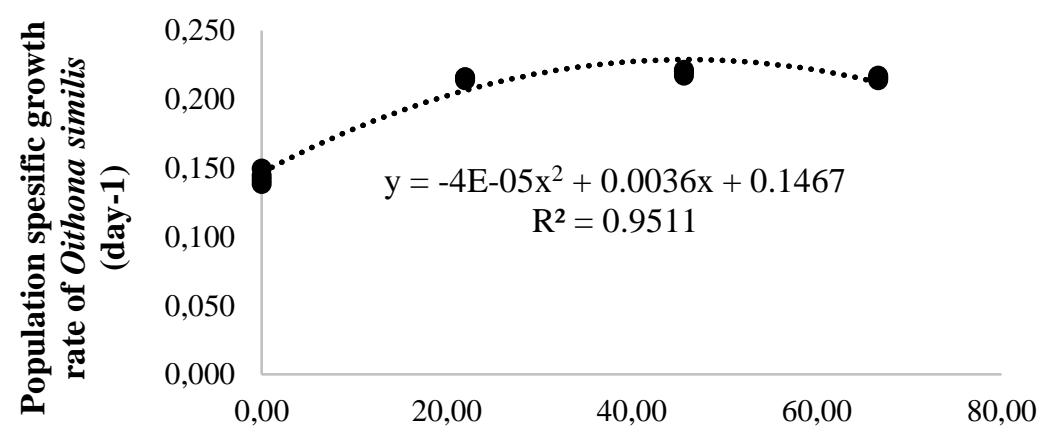

Aeration Flow Rate (mL.second ${ }^{-1}$ )

Figure 6. Correlation between aeration flow rate culture medium and the population specific growth rate of $O$. similis

\subsubsection{Egg production of O. similis}

The average histogram of $O$. similis egg production at the end of the observation (Figure 7) showed that culture medium with an aeration flow rate of $45.67 \mathrm{~mL}$.second ${ }^{-1}$ gave the highest egg production $\left(28.40 \pm 0.48\right.$ egg.ind $\left.^{-1}\right)$ which was significantly different $(\mathrm{p}<0.05)$ with all three other treatments. The aeration flow rates of 66.67 and 22.00 mL.second ${ }^{-1}$ generated egg production which was not significantly different $(p>0.05)$ but was significantly different from the aeration flow rate of $0.00 \mathrm{~mL} \cdot \operatorname{second}^{-1}\left(7.05 \pm 1.84\right.$ egg.ind $\left.{ }^{-1}\right)$.

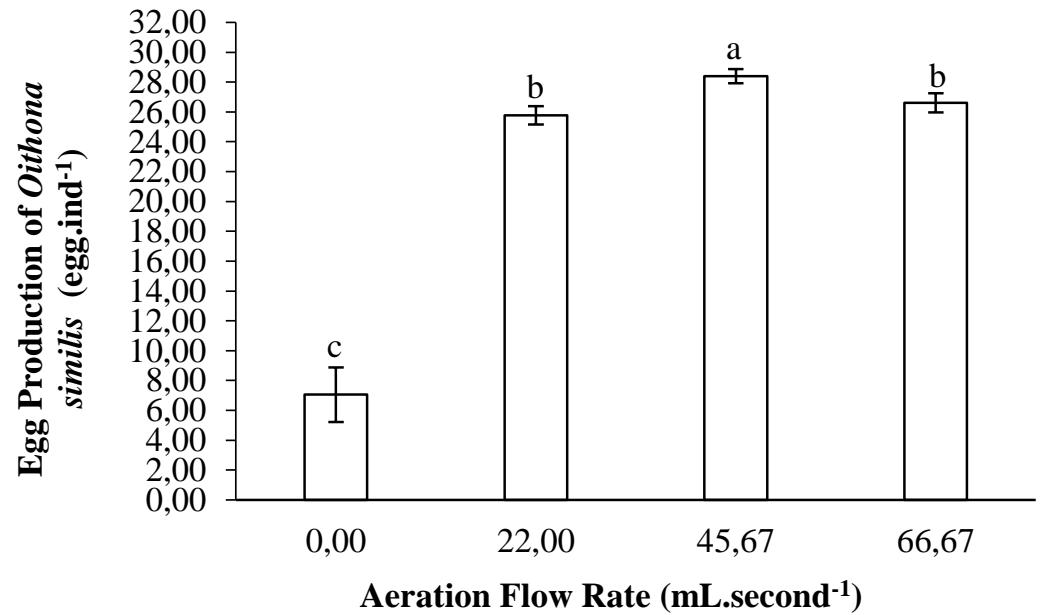

Figure 7. Egg production of $O$. similis in different aeration flow rate culture medium

Based on the orthogonal polynomial test of $O$. similis egg production on culture medium with different differences in aeration flow rate, quadratic patterned relationships (Figure 8) were obtained with the equation $y=-0.0105 x^{2}+0.9723 x+7.6696$ with $R^{2}=0.9649$ and the optimum point of media aeration flow rate at $45.7 \mathrm{~mL}$.second ${ }^{-1}$. This showed that $O$. similis egg production was influenced by the aeration flow rate factor of $96.49 \%$ and another factor of $3.51 \%$. 


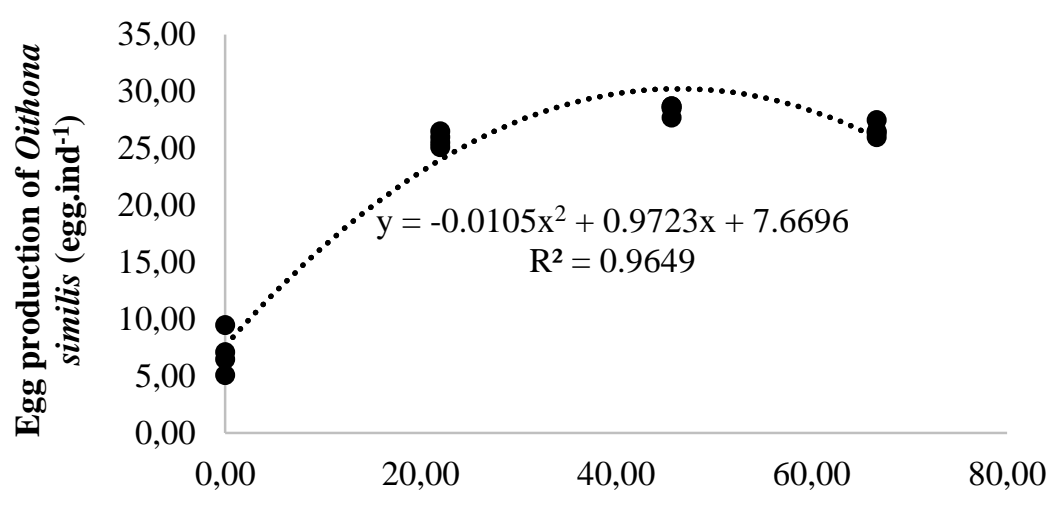

Flow rate aeration culture medium (mL.second $\left.{ }^{-1}\right)$

Figure 8. Correlation between aeration flow rate culture media and egg production of $O$. similis

\section{b. Discussion}

The results of water quality measurement from each different aeration flow rate show a range which is still suitable for $O$. similis life. The correlation of aeration flow rate and DO showed a simple linear correlation, where DO content will increase in line with the increase in aeration flow rate in $O$. similis culture media (Figure 2). This proves that there was a closeness in the relationship between the flow rate of aeration and DO.

The results showed that the difference in aeration flow rate has a significant effect on total density, specific population growth rate, and reproduction of $O$. similis. Treatment of $\mathrm{C}$ (aeration flow rate $45.67 \mathrm{~mL} . \mathrm{second}^{-1}$ ) with DO $4.18 \mathrm{mg} . \mathrm{L}^{-1}$ produced the highest of total density, population specific growth rate and egg production among the other treatments. It was suspected that the magnitude of the aeration flow rate has provided environmental conditions that in accordance with the needs and supports the growth and reproduction of $O$. similis. In addition, the movement of water generated by the aeration flow rate provided suitable conditions for the movement of $O$. similis in the water column. The environmental conditions of culture media that did not support will affect the growth and SR of Oithona sp. [13]. In nature, the factors that influence the population of copepoda (Oithona sp.) beside feed availability [14] are fish larvae (predators), other copepods (competitors), and abiotic factors, i.e. temperature, DO and salinity [15].

The observation during the study showed that the difference in the aeration flow rate had a different effect on the water movement in the $O$. similis culture media. Physically, treatment B showed a quieter water movement, but DO was lower than treatment C and D. This will relatively affect the growth and reproduction of $O$. similis because oxygen was also needed by phytoplankton Chaetoceros calcitrans. The presence of fermented organic food (feed organic fermented) added will also affect the DO content in the $O$. similis culture media. It was predicted that in treatment B the DO content was still insufficient for $O$. similis to grow and reproduce.

Treatment $\mathrm{D}$, water movement was too strong that suspected as the stress factor for $O$. similis. These stress conditions will affect the use of a certain amount of energy to recover [16]. Copepode $O$. similis required sufficient energy to maintain its life so that the energy that should be allocated for growth was disrupted. This strong water movement causes 
deposits of organic feed and other impurities at the bottom to stir up. The movement of $O$. similis to defend itself from the flow due to the movement of a large aeration flow rate also reduces the energy that is supposed to grow and metabolize.

Treatment A where culture media without aeration showed the lowest DO (2.50 mg.L $\left.{ }^{-1}\right)$. The DO content was still feasible for the life of $O$. similis even though it provided the lowest growth and egg production performance. [17] stated that copepods could no longer tolerate DO $<1.1 \mathrm{ppm}$ as well as [18] stated that the minimum DO concentration that was still tolerated by copepod was $2 \mathrm{ppm}$. This is in accordance with the results of the research by [19] that copepods from the species Calanipeda aqvaedulcis and Arctodiaptomussalinus can grow well with a range of DO 1-8 ppm.

The values of temperature, $\mathrm{pH}$ and ammonia content in $O$. similis culture media (Table 1 ) are presumed to support the life of $O$. similis especially for its growth and egg production. The measurement results of temperature, $\mathrm{pH}$ and ammonia during the study of all treatments were still at a reasonable level for the life of $O$. similis. The optimum temperature range of copepod is $25^{\circ} \mathrm{C}$ [15]; $25-30^{\circ} \mathrm{C}$ [33]. Temperature plays an important role in the rate of metabolism and egg production [14]. Temperature affects the size of the female, which also affects egg production [20]. [22] reported copepod nauplii grow well at $\mathrm{pH}$ 7.7-8.5 and could tolerate ammonia $\leq 1.3 \mathrm{ppm}$. Low temperatures will increase total body length and prolong the growth and maturation of copepods [34]. In addition, temperature also affects the quality of copepods' nutrition. As an example, PUFA (Polyunsaturated Fatty Acid) content will increase at low temperature [33].

Based on the specific population growth rate, the optimum aeration flow rate for $O$. similis culture was $45.70 \mathrm{~mL}$.second ${ }^{-1}$. In the optimum conditions will provide suitable and preferred environment to the high density, population specific growth rate and egg production of $O$. similis.

\section{Conclusions}

The difference in aeration flow rate have a significant effect $(\mathrm{p}<0.05)$ on growth performance and egg production of Oithona similis where $45.67 \mathrm{~mL}$.second ${ }^{-1}$ aeration flow rate showed the best growth and egg production performance (total density of $81.25 \pm 2.99$ ind. $\mathrm{mL}^{-1}$; specific population growth rate of $0.220 \pm 0.002$ day $^{-1}$, and egg production of $28.40 \pm 0.48 \mathrm{egg}_{\text {.ind }}{ }^{-1}$. Based on the specific population growth rate, the optimum aeration flow rate for $O$. similis culture was $45.70 \mathrm{~mL}$. second $^{-1}$.

This research was funded by Lembaga Pengelola Dana Pendidikan (LPDP) through program Beasiswa Unggulan Dosen Indonesia Dalam Negeri (BUDI DN).

\section{References}

1. J.S. Broach, E.J. Cassiano, C.A. Watson,Baseline culture parameters for the cyclopoid copepod Oithona colcarva: a potensial new live feed for marine fish larviculture. Aquaculture Research 48, 4461-4469 (2017).

2. M.Y. Leu, P.J. Meng, K. Siong Tew, J. Kuo, C.C. Hung, Spawning and development of larvae and juveniles of the indian ocean oriental sweetlips, Plectorhinchus vittatus (Linnaeus 1758) in the aquarium, Journal of the world aquaculture society 43, 595-606 (2012).

3. D. Chilmawati, J. Hutabarat, A. Anggoro, Suminto,Biomolekular identification and optimization of growth performance and egg production in Oithona sp. under different salinity culture conditions, AACL Bioflux 12, 2, 575-585 (2019). 
4. Suminto, D. Chilmawati, D. Harwanto, The effect of fermented organic feed on the performance of Oithona sp. in semi-mass culture condition, Omni-Akuatika 14, 3, 5359 (2018).

5. R. Almeda, C. B. Augustin, M. Alcaraz, A. Calbet, E. Saiz, Feeding rates and gross growth efficiencies of larval developmental stages of Oithonadavisae (Copepoda, Cyclopoida), Journal of Experimental Marine Biology and Ecology 387, 24-35 (2010).

6. D. Chilmawati, Suminto,The effect of different diet of phytoplankton cells on growth performance of copepod, Oithona sp. in semi-mass culture, Aquatic Procedia 7, 39-45 $\left(2016^{\mathrm{a}}\right)$.

7. L. Creswell, Phytoplankton culture for aquaculture feed. Southern regional aquaculture center, SRAC Publication No. 5004. 16 (2010).

8. K.W. Lee, H.G. Park, S.M. Lee, H.K. Kang, Effect of diets on the growth of the brackish water cyclopoid copoped Paracyclopina nana Smirnov, Aquaculture 256, 346-353 (2006).

9. Suminto, D. Chilmawati, T. Susilowati, I. Adhinugroho, The effects of microalgal diet with enrichment of fermented organic matters (Tofu waste, Rice bran, and fish meal) on growth and reproduction of Diaphanosoma brachyurum. $4^{\text {th }}$ International Conference on Tropical and Coastal Region Eco Development. IOP Publishing. IOP Conf. Series: Earth and Environmental Science 246 012036. Doi:10.1088/17551315/246/1/012036 (2019).

10. Takahashi, T., I. Uchiyama, Morphology of the naupliar stages of some Oithona species (Copepoda: Cyclopoida) occurring in Toyama Bay, Southern Japan Sea. Plankton Benthos Research, 2(1): 12 - 27 (2007).

11. S. Zamora-Terol, R. Swalethorp, S. Kjellerup, E. Saiz, T.G. Nielsen, Population dynamics andproduction of the small copepod Oithona sp. in a subarctic fjord of West Greenland,Polar Biology 37, 953-965 (2014).

12. S. Cheng, K. Samba, R. Kumar, K. Chung-Su, H. Jiang-Shiou, Effect of salinity, food level, and the presence of microcrustcean zooplankters on the population dynamics of rotifer Brancionus rotundiformis, Hydrobiologia 666, 289-299 (2011).

13. S. Diekman, A.B. Clemmesen, C. Ast. Jonh, M. Paulsen, A. Peck, Environmental cues and coastrain affecting the seasonality of Dominant Calanoid Copepods in brackish, coastal waters: a case study of Acartia, Temora and Eurytemora species in the southwest Baltic, Marine Biology 159, 2399-2414 (2012).

14. M. Noyon,P.W. Froneman, Variability in the egg production rates of the calanoid copepod, Pseudodiaptomus hessei in a South African estuary in relation to environmental factors. Estuarine, Coastal and Shelf Science 30, 1-11 (2013).

15. D. Beyrend-Dur, R. Kumar, T.R. Rao, S. Souissi, S.H. Cheng, J.S. Hwang, Demographic parameters of adults of Pseudodiaptomus annandalei (Copepoda: Calanoida): temperature-salinity and generation effect. Journal of Experimental Marine Biology and Ecology 404, 1-14 (2011).

16. F.K.F. Chua, M.G.S. Yap, S.K.W. Oh, Hyper stimulation of monoclonal antibody production by high osmolarity stress in eRDF medium, Journal of Biotechnology 37, 265-275 (1994).

17. H. Auel, H.M. Verheye, Hypoxia tolerance in the copepod Calanoides carinatus and the effect of an intermediate Oxygen minimum layer on copepod vertical distribution in the Northem Benguela current upwelling system and the Angola-Benguela Front, J.Exp. Mar. Biol. Ecol. 352, 234-243 (2007). 
18. CJ. Cass,K.L. Daly,Eucalanoid copepod metabolic rates in the oxygen minimum zone of the Eastern tropical north pacific: the effects of oxygen and temperature, Deep Sea Res. Part I 94, 137-149 (2014).

19. L. Svetlichny, A. Khanaychenko, E. Hubavera, L. Agasenova, Partitioning of respiratory energy and environmental tolerance in the copepods Calanipeda aquaedulcis and Arctodiaptomus salinus, Estuar. Coast. Shelf Sci. 114, 199-207 (2012).

20. Nanton B.W. Hansen, G. Drillet, A. Kozmer, K. V. Madsen, M. F. Pedersen, T. E. Sorensen, Temperature Effects on Copepod Egg Hatching: Does Acclimatization Matter?, Journal of Plankton Research,32, 3, 305- 315 (2010).

21. A.L. Rhyne, C.I. Ohs, E. Stenn, Effect of temperature on reproduction and survival of the calanoid copepod Pseudodiapnotus pelagicus, Aquaculture 292, 53-59 (2009).

22. B.K. Sullivan, P.J. Ritacco, Ammonia toxicity to larvae copepods in eutrophic marine ecosystems: A comparison of results from Bioassay and enclosed experimental ecosystems, Aquatic Toxicology 7, 205-217 (1985).

23. B.W. Hansen, G. Drillet, A. Kozmer, K. V. Madsen, M. F. Pedersen, T. E. Sorensen, Temperature Effects on Copepod Egg Hatching: Does Acclimatization Matter?, Journal of Plankton Research,32, 3, 305- 315 (2010).

24. D. Chilmawati, Suminto,Growth performance of Oithona sp. with combination of phytoplankton cells and feed organic fermented in mass culture conditions, Proceeding of Annual Seminar of Fisheries and Marine Science VI, Faculty of Fisheries and Marine Science, Diponegoro University, ISSN:2339-0883, page 706-715 $\left(2016^{\text {b }}\right)$ [in bahasa Indonesia].

25. E.J. Cassiano, C.L. Ohs, C.R. Welrich, N.E. Breen, A.I. Rhyne, Performance of larval Florida pompano Trachinotus carolinus, fed nauplii of the calanoid copepod Pseudodiapnotus pelagicus, North American Journal of Aquaculture 73, 114-123 (2011).

26. G. Drillet, S. Frouel, M.H. Sichlau, P.M. Jepsen, J.K. Hojgaard, A.K. Joarder, B.W. Hansen,Status and recommendation on marine copepod cultivation for use as live feed, Aquaculture 315,155-166 (2011).

27. I. Olivotto, N.E. Tokle, V. Nozzi, L. Cossignani, O. Carnevali, Preserved copepods as a new technology for the marine ornamental fish aquaculture: a feeding study, Aquaculture, 308, 124-131 (2010).

28. K. Lee, Cdu, Mhorn, L. Rabinow,Activity and autophosphorylation ofLAMMER protein kinases, J Biol Chem. 271, 44, 27299-303 (1997).

29. K.W. Lee, H.G. Park, Effects of temperature and salinity on productivity and growth offive copepod species, J. Kor. Fish. Soc. 38, 12-19 (2005).

30. M.F. Payne, R.J. Rippingale, Evaluation of diets for culture of the calanoid copepod Gladioferens imparipes, Aquaculture, 187, 85-96 (2000).

31. O.G.H. Molejon, A. Lajonchere, Culture experiments with Oithona oculata Farran, 1913 (Copepoda: Cyclopoida), and it's advantages as food for marine fish larvae, Aquaculture 219,471-483 (2003).

32. P. Lavens, P. Sorgeloos,Introduction. In: Manual on the production and use of live food for aquaculture. Lavens P., Sorgeloos P. (eds), FAO Fisheris Technical Paper, No. 361, FAO of the United Nations, Rome, 1-6 (1996).

33. S. Chullasorn. Two new species of Paramphiascella Lang (Copepoda: Harpacticoida: Miraciidae) from a brackish water pond in Thailand, Zootaxa, 2634; pp.1-24 (2010). 
34. H. Miliou. and M. Moraitou-Apostolopoulou. Combined effects of temperature and salinity on population dynamics of Tisbe holothuriae Humes (Copepoda: Harpacticoida\}. Arch. Hydrobiol. 121,431-448 (1991). 